\title{
Analysis of Pioneering Raskin Innovation for the Pattern of Labor-Intensive Food in North Central Timor District
}

\author{
Ane Rupaiedah ${ }^{1^{*}}$, Kismartini ${ }^{2}$, Ida Hayu Dwimawanti ${ }^{3}$ \\ ${ }^{1 *}$ Master of Public Administration Study Program, Department of Public \\ Administration, FISIP, Diponegoro University Semarang \\ ${ }^{2}$ Department of Public Administration, FISIP, Diponegoro University, Semarang \\ ${ }^{3}$ Department of Public Administration, FISIP, Diponegoro University, Semarang \\ Corresponding Author: ${ }^{1 *}$ rupaiedab@gmail.com
}

Article History:

Submit:

2021-05-25

Publish:

2021-06-14

\section{Abstract}

This research is intended to analyze the Pioneering of the Raskin Innovation for Food Labor Intensive Patterns in North Central Timor District. The problem in this research is how the stages of pioneering Raskin innovation for food labor in the North Central Timor district. To answer this problem, various theories are relevant to the research phenomenon. This research uses descriptive qualitative method with data analysis techniques Milles and Huberman. The results of the Raskin Innovation Research on Food Labor Intensive Patterns in North Central Timor Regency, namely: 1.In the Raskin Innovation Initiation phase, PKP was formulated by identifying agricultural problems in TTU Regency so that the Innovation concept was indeed appropriate to answer the problem, then the PKP Raskin innovation adjusted to several criteria, namely new concepts, finance, technical capabilities, and public support. However, in adjustment there are problems that need to be reviewed and improved in the PKP Raskin innovation guidelines.

Keywords: Innovation, Food Labor Intensive Patterns Raskin. 
Journal Homepage http://ijssr.net/index.php/ijssr

This is an Open Access article under the CC BY SA license

https://creativecommons.org/licenses/by-sa/4.0/

Published by

Indonesian Academy of Social and Religious Research

\section{Introduction}

Regional governments with regional autonomy have the authority to formulate policies and develop infrastructure based on regional aspirations and needs. District and city governments can respond more responsively to problems that occur in their regions by improving the quality of public services. Public services are closely related to the challenges and opportunities in the current era of globalization, the government as a public servant must serve maximally and with high quality that is tailored to the demands of the needs desired by the public. ${ }^{1}$

High service quality is a must for public organizations so that services are easily available, affordable and equitable. ${ }^{2}$ In developing a public service, innovation is needed as a new invention that can replace the existing methods. This means that every public service basically must have the latest breakthroughs so that it can improve service quality and meet public needs properly.

Innovation is a result of the creation of something that is considered new which is intended to solve problems, whether in the form of ideas, goods, events, methods and so on carried out by a person / group. Public service innovation also plays an important role in the development of public management because innovation can answer various demands of society. Innovation is seen as one of the keys to today's long-term success. ${ }^{3}$ Discussion on public service innovation is currently crucial in providing public services in Indonesia where the current conditions of globalization and science and technology (IPTEK) are developing more rigorously and openly. Service, which is the process of meeting needs directly through the activities of other people, is a real concept in all institutional aspects. ${ }^{4}$ This concept has developed widely in addition to business organizations when it

1 Anggaraeny, Cindy.2013, Inovasi Pelayanan Kesehatan Dalam Meningkatkan Kualitas Pelayanan Di Puskesmas Jagir Kota Surabaya, Jurnal Kebijakan dan Manajemen Publik, Vol 1., No.1 Januari 2013, Unair Surabaya.

2 Suwarno, Yogi. 2008. Inovasi di Sektor Publik, Stia-Lan Jakarta.

3 Erna Setijaningrum. 2016. Inovasi Kebijakan Pelayanan Publik : Best Practice di Indonesia. Airlangga University Press.

4 Sinambela, 2013. Reformasi Layanan masyarakat, PT Bumi Aksara Jakarta. 
is developing into governmental organizations. Thus, every public institution and organization needs and continues to innovate in facing the demands of public needs in line with the changing times. Innovation is the result of the process of developing and utilizing existing products or resources and providing added value to be more effective and efficient.

In order to encourage innovation in public services, the Ministry of State Apparatus Empowerment and Bureaucratic Reform of the Republic of Indonesia created a public service innovation competition within the scope of ministries, public organizations, central and regional governments and their business institutions with the aim of creating quality public services to meet the expectations of the Indonesian people.

Public service innovation competitions are activities of selecting, assessing, and giving awards every year. Public service innovations that take part in the selection need to meet several requirements, namely: 1 . Improving public services, 2. Benefits for all people, 3. Able and / or replication has been made, 4. Continuous, 5. The innovation is carried out for at least 1 (one) year ${ }^{5}$.

North Central Timor Regency is one of several districts that won the top 40 public service innovations with the Food-Rich Pattern Raskin Innovation Program (PKP) which competed from 2,824 public service innovations in the 2018 public service innovation competition. With the issuance of the Decree of the Minister of Administrative Reform and Bureaucratic Reform (PANRB) No. 636/2018. The innovations that won the Top 40 Public service innovations in 2018 were innovations selected from the Top 99 so that they were categorized as outstanding innovations (praiseworthy). The assessment of the competition is carried out by the Evaluation Team and the Independent Panel Team consisting of academics, practitioners, and experts with good competence and reputation. ${ }^{6}$

The Raskin Innovation for the Food Labor Intensive Pattern is an innovation that is different from the general Raskin assistance that exists throughout Indonesia, where the food labor-intensive pattern is defined as an effort to maximize the effectiveness and efficiency of the Raskin program management by weighting more work on farmer family organizations, land management work. cooperative agricultural efforts, assisting, coordinating, supervising and evaluating so that the

PerMenPan RB No 03 Tahun 2016

6 https://www.menpan.go.id/site/berita-terkini/kementerian-panrb-tetapkan-top-40-inovasipelayanan-publik-2018 
cooperation is getting stronger towards food security and food sovereignty of the farming family. ${ }^{7}$ This means that Raskin assistance provided to the poor is not free but is provided if the poor community has permanent processing plantations.

The indicators for achieving the Raskin program for the Food Labor Intensive Pattern are as follows:

a) Output

The food labor-intensive outputs are as follows:

1) RTS-PM PKP (Target Households for Food Labor-Intensive Beneficiaries) can expand agricultural land processing with intensive management including fertilizers and terraces.

2) RTS-PM PKP (Target Households for Food Work-Intensive Beneficiaries) can cultivate longevity and seasonal crops of superior quality for the realization of farmer pension.

3) RTS-PM PKP (Target Households for Food Work-Intensive Beneficiaries) can cultivate longevity plants to survive until they produce products that are used as savings for old age (farmer pension).

4) RTS-PM PKP (Target Households for Food Work-Intensive Beneficiaries) can add knowledge and skills according to the farming business being run.

b) Result

The results of PKP (Food Labor Intensive) are as follows:

1) There is an improvement in the quality of life of the poor by increasing agricultural productivity, both long-life and seasonal crops that rely on rainwater and irrigation water.

2) RTS-PM PKP (Target Household Beneficiaries of Food Labor Intensive) at least have a permanent garden of 100 acres with long life plants for savings in old age.

3) There is an increase in household income per capita of RTS-PM PKP (Target Households for Food Intensive Beneficiaries)

4) There is an increase in the contribution of the agricultural sector to the formation of GRDP (Gross Regional Domestic Product)

5) There is an increase in the economic growth of North Central Timor district. $^{8}$

Dinas Pertanian Tanaman Pangan dan Perkebunan Kabupaten Timor Tengah Utara, 2014.

8 Petunjuk Teknis Inovasi Pola Padat Karya Pangan 2014. 
Even though the Raskin PKP (Food Intensive Work) Innovation is included in the top 40 public service innovations of Kemenpan RB 2018, there are problems that are contrary to this innovation. Where in Permenpan No. 03 of 2018 says a government agency initiative that is said to be innovation if it is real and measurable through improving services, processes, systems or the concept of running government so it is clear that an innovation is not just a concept but a continuation of real action from the concept so that it is useful for the community.

Then the researchers looked at the Raskin innovation process for the Food Labor Intensive Pattern as according to Rogers, ${ }^{9}$ who explained that in the innovation process there are two phases that need to be considered the initiation / pioneering phase and the implementation / implementation phase. In the first phase, namely the initiation / pioneering phase, there are two stages, namely 1 . the agenda setting stage which identifies in determining the main scale of needs and problems that occur in North Central Timor district. Next, look for and determine a place in the organization for the application of the Raskin PKP innovation. 2. The matching stage is the stage of adjusting or equalizing the current situation with the adoption of innovation. This matching stage provides certainty of Feasibilities or the feasibility of applying the innovation in the target organization or community. In connection with the matching phase of natural and human resources, it provides support for the application of an innovative Raskin pattern for food labor-intensive patterns. The natural resource support referred to is the aspects of land and agricultural land area in the North Central Timor district. Based on the ground aspect, this area is on a slope of not more than $40 \%$ with an area of $2,065.19 \mathrm{~km} 2$ or $77.4 \%$ of the total area of TTU; while the remaining $604.51 \mathrm{~km} 2$ or $22.6 \%$, the slope rate exceeds $40 \%$. Most of the areas with a slope of not more than $40 \%$ are not more than $500 \mathrm{~m}$ high from sea level, covering an area of $1676.51 \mathrm{~km} 2$ or $62.8 \%$. Three sub-districts that have unstable land that is prone to partial erosion include West Miomaffo 37,921 hectares, South Biboki 28,538 hectares, and North Biboki 28,538 hectares ${ }^{10}$. From the data above, it can be said that the amount of productive land for agriculture is very small. Another thing shows that there is still a lot of idle agricultural or nonproductive land that has not been processed by the community. This condition is supported by the graph in Figure 1.1 Land Use in North Central Timor District.

\footnotetext{
9 Rogers, Everett, M. (2003). Diffusions of Innovations; Fifth Edition. Simon \& Schuster Publisher. 10 Badan Pusat Statistik BPS TTU,(2019).
} 
Figure 1.1

Land Use in North Central Timor District 2018

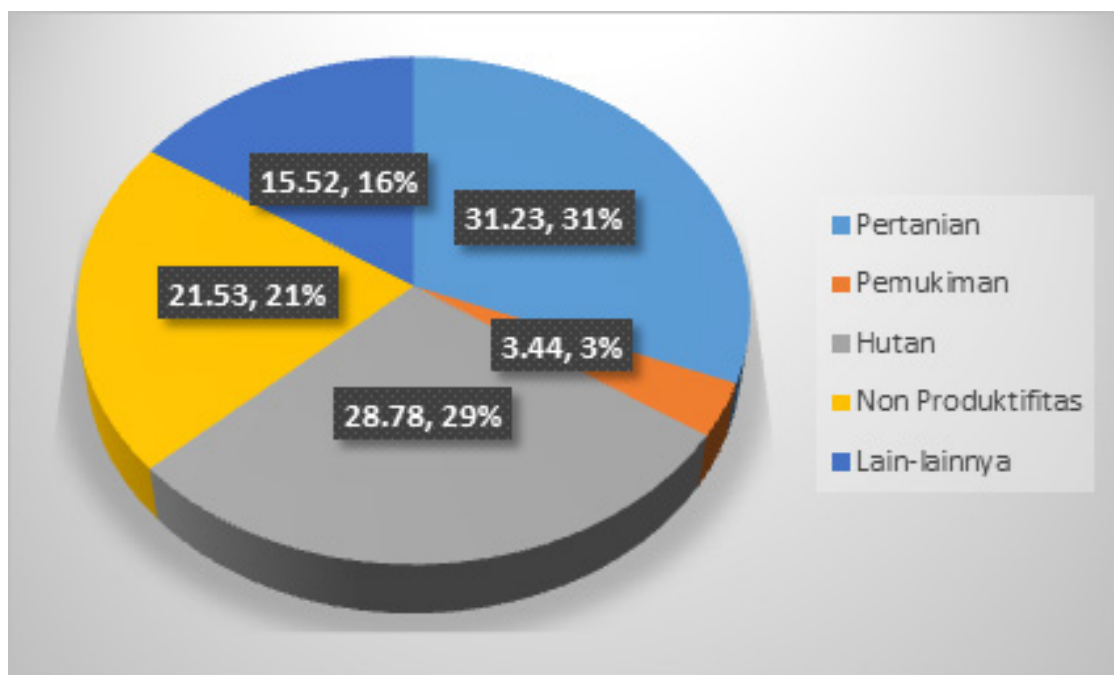

Source: The Human Settlements Division of TTU Regency $2018^{11}$

Based on the data above, land use in the North Central Timor district is mostly used for the agricultural sector, namely $31.23 \%$ or 97,948 ha, consisting of rice fields: 11,366 ha, dry fields: 55,732 ha, plantations: 30,850 ha. However, there are still many unused agricultural lands that have not been processed by the community into agricultural land, so this has an effect on the application of Raskin innovations for food labor-intensive patterns.

One of the Raskin Innovations in the Food and Labor Intensive Patterns is as a poverty alleviation program in North Central Timor district. With regard to the innovation, the PKP Raskin can realize food security in TTU Regency so that it can improve the welfare of the community. However, the problem that occurs in the poverty rate in North Central Timor Regency is fluctuating every year so that poverty alleviation programs, one of which is the innovation of the PKP Raskin, has not been maximized in its implementation. The picture of poverty in North Central Timor Regency can be seen from the number of poor people, and per capita income as shown in table 1.1 below

11 Bidang Cipta Karya Kabupaten TTU, 2018 
Table 1.1

Number and Percentage of Poor Population in North Central Timor District Year 2012-2019

\begin{tabular}{ccc}
\hline Year & Poor People & Percentage of Poor Population \\
\hline 2012 & 51,20 & $21,53 \%$ \\
2013 & 51,80 & $21,37 \%$ \\
2014 & 50,72 & $20,89 \%$ \\
2015 & 61,96 & $25,20 \%$ \\
2016 & 59,34 & $24,07 \%$ \\
2017 & 58,59 & $23,52 \%$ \\
2018 & 56,09 & $22,31 \%$ \\
2019 & 56,94 & $22,45 \%$ \\
\hline
\end{tabular}

Source: processed from BPS Province of NTT $2020^{12}$

Based on the table above, it shows that the percentage of poor people in North Central Timor district has fluctuated, namely in 2012 to 2014 there was a decrease in the poverty rate, from $21.53 \%$ to $20.89 \%$, but increased in 2015 to 25.20\% and decreased and fluctuated again until 2019 reaching $22.45 \%$ higher than 2018, namely $22.31 \%$. This also shows that the Raskin innovation in the food labor-intensive pattern that aims to alleviate poverty in North Central Timor Regency which has been implemented since 2012 has not been maximized because there are still many poor people and the reduction in the poverty rate in TTU district from 2012 to 2019 is fluctuating.

Regarding the condition of the beneficiary community, it will also affect the matching stage in a human resource innovation, in this case, the TTU district community as the beneficiary of the innovation so that they can apply the aims of the Raskin innovation for the food labor-intensive pattern.

Based on problems related to the PKP Raskin Innovation (Food Intensive Workforce), which has not provided benefits to the community as shown by the community still farming with traditional systems / patterns, it has not been maximally replicated to work units, resulting in weak coordination at the village level regarding the PKP Raskin innovation.. This problem has attracted researchers

12 Badan Pusat Statistik BPS Provinsi NTT 2020 
to research in relation to the Pioneering Process of the Raskin Innovation for Food Labor Intensive Patterns in North Central Timor District.

\section{Literature Review}

\subsection{Innovation}

Innovation is a new concept in the public administration literature. The origin of the word innovation is the Latin word innovare, which means to change something into new things. Innovation (innovation and innovate) began to be used in English around the 16th cen The definition of innovation in the Big Indonesian Dictionary tury. ${ }^{13}$ namely the activity of entering or introducing new things from what has been known or existed before (ideas, methods or tools).

Meanwhile, the definition of innovation according to Ancok ${ }^{14}$ In his book Psychology of leadership and innovation, namely "a process of thinking about and implementing these thoughts so as to produce new things in the form of products, services, business processes, new methods, policies and so on." ${ }^{15}$ Meanwhile ${ }^{16}$, Anthony defines innovation in simpler terms, namely as "something different that has an impact".

Van den Ban \& Hawkins ${ }^{17}$ defines innovation as an idea or method with new things that result from trusted research. Furthermore, according to Clark, Jhon and Ken Guy ${ }^{18}$ innovation is the result of development that provides added value or the process of utilizing knowledge, skills and experience for the creation and renewal of products (goods and services), processes or systems. Hurley and Hult understand innovation in the process of adapting to a dynamic environment, as a dynamic organization that must be able to generate ideas, as well as new products and services that increase and provide satisfaction to consumers. ${ }^{19}$

The definition of innovation has various definitions by experts. Through the understanding of innovation according to experts, innovation is understood as a process of thinking and implementing ideas with new elements and benefits.

13 Kamus Besar Bahasa Indonesia Pusat Bahasa Edisi Keempat. Jakarta: PT. Gramedia Pustaka Utama.

14 Ancok, Djamaludin. 2012. Psikologi Kepemimpinan dan Inovasi. Jakarta : Erlangga.

15 David O'Sullivan Lawrence Dooley, 2009. Applyng Innovation. Thousand Oaka, CA: Sage

16 Anthony, Scott.d. 2013. The Little Black Book Of Innovation Sage Publication, inc.

17 Van Den Bar, A.W Den Hawkins. 2005. Penyuluhan Pertanian Agriculture Extension. Kanisius. Yogyakarta.

18 Clark, Jhon \& Ken Guy . 1997. Innovation And Competitiveness. Techopolis.

19 Hurley, Robert Hult, Tomas M.Hult, 1998. Innovation, Market Orientation And Organizational Learning : An Integration And Emperical Exampirical" Jurnal of Marketing. 
In relation to public administration, innovation is understood as a process of thought and implementation of policies with new elements and benefits by the public administration for the fulfillment of the public interest.

The government needs to make innovations in improving public services given the changing conditions in the environment. Innovation is an organization's effort to survive in the environment. The existence of innovation in this organization is expected to be able to respond to complex environments and changing environmental dynamics, especially in fierce competition so as to create a superior source of competition.

\subsection{Innovation Application Process}

There is a difference between the innovation process of public sector organizations and the individual innovation processes. In public sector organizations, the adoption of innovation goes through several stages, among others ${ }^{20}$ :

a) Initiation or pioneering

The initiation or pioneering stage begins with gathering information, then making concepts and plans as material for discussion until an innovation is obtained. This stage is divided into two phases, namely agenda setting and matching. The pioneering stage is the beginning in recognizing the situation and understanding organizational problems.

1) At the agenda setting stage identifies priority needs and problems. Then look for the right place to apply innovation in an organizational environment. This stage takes a long time. There is a performance gap or performance gap that triggers innovation in an organization.

2) Matching phase or adjusting or equalizing the situation to the adoption of innovation. This stage provides certainty of the feasibilities or feasibility of the innovation application for the organization.

b) Implementation or implementation

In the implementation stage, the pioneers have decided on the search and acceptance of innovation as problem solving in the organization. This stage is divided into three phases, among others:

${ }_{20}$ Rogers, Everett, M. (2003). Diffusions of Innovations; Fifth Edition. Simon \& Schuster Publisher. 
1) The redefining phase is marked by the loss of the foreign character of the adoption of innovation. Innovation has gone through a re-invention process so that it can provide accommodation and definition of organizational needs and undergo adjustments. Usually accompanied by changing organizational hierarchies and organizational leadership.

2) The clarifying phase is the widespread use of organizational innovation and affects all parts of the organization in the routine of its work. This clarification phase takes a long time because it affects the overall habits of the organization so that many fail to implement it. Adoption is counterproductive if it is too fast because of excess barriers.

3) The routinizing phase considers innovation to be an element of the organization. The character of innovation is not a new product or method and has become a routine in organizing an organization.

This research will further analyze at the piloting stage of the Raskin Innovation for Food Labor Intensive Patterns in North Central Timor District. The Pioneering Stage is the initial stage in compiling and accepting innovations that have been deemed capable of solving problems faced both in an organization and in public services. In this study, the pioneering stages of the Raskin innovation for labor-intensive food patterns consisted of: the setting agenda phase, and the matching phase.

\section{Method Of Research}

The method used in this research is descriptive qualitative with an exploratory approach. The focus of this research is to analyze the Pioneering of the Raskin Innovation for Food Labor Intensive Patterns in North Central Timor District. The data collection techniques in this study were interviews, observation and document study, while the data analysis techniques were Miles and Huberman. ${ }^{21}$

${ }^{21}$ Sugiyono. (2011). Metode Penelitian Kuantitatif, Kualitatif dan REDD. Bandung: Penerbit Alfabeta. 


\section{Discussion}

\section{The stages of Initiation or the pioneering of the Raskin Innovation for Food Labor Intensive Patterns}

Innovation in public administration can be interpreted as a process of thinking about and implementing a policy by administrators of the public interest in fulfilling public needs that have a novelty, a breakthrough in its use. Innovation is very important for the government and public organizations to improve the quality of public services following the changing times and environmental conditions that occur. Innovation is also an attempt to maintain a government organization in the environment. With the existence of organizational innovation, it is hoped that it will be able to respond to the complexities of public problems that are dynamic in the era of civilization.

The innovation process for organizations is different from the processes that occur individually. Where innovation in organizations, especially the public sector, must go through the initiatiaon or pioneering stages ${ }^{22}$. The initiation or pioneering stage is a process where all information is collected, identified, conceptualized and then planned to make an innovation as a solution to the public problems faced.

\section{The Agenda Stage for Setting the Raskin Innovation for Food Labor Intensive Patterns in North Central Timor District}

At this stage, the agenda setting identifies priority needs and problems. Then look for the right place to apply innovation in an organizational environment. This stage takes a long time. There is a performance gap or performance gap that triggers innovation in an organization ${ }^{23}$. It can be interpreted that the agenda setting stage is the identification and formulation of organizational problems or public issues in order to determine the need for innovation, and an environmental study is held to determine the potential value of innovation for the organization.

The results of the study are related to the Agenda for setting the Raskin innovation for food-intensive patterns in North Central Timor. springs, drought, and agricultural yields are not maximized so that they always encounter crop failure disaster. The problems that occur require a solution to overcome so that people can slowly leave the agricultural system of the slash-and-burn pattern

22 Rogers, Everett, M. (2003). Diffusions of Innovations; Fifth Edition. Simon \& Schuster Publisher.

23 Rogers, Everett, M. (2003). Diffusions of Innovations; Fifth Edition. Simon \& Schuster Publisher. 
which is detrimental to the environment and to meet community needs. Thus, the Food Crops and Plantation Office of North Central Timor Regency based on the problems that occurred through the Agriculture and Plantation Service made new innovations to improve the correct community agricultural system and use of agricultural land that was effective and efficient in minimizing traditional agricultural patterns so as to create food security for TTU district community.

Thus it can be concluded that the food labor-intensive pattern Raskin innovation has gone through the agenda setting stage in its formulation, wherein the food labor-intensive pattern Raskin innovation was born from a major problem in the community of TTU district, namely still implementing a slashand-burn agricultural system that has many impacts. on other new problems such as environmental destruction, lack of clean water sources due to deforestation due to slash and burn patterns in agriculture, and food insecurity and crop failure that always surrounds the people of North Central Timor. Raskin innovation in the food-intensive pattern of labor has identified this problem in a short time so that it can formulate new concepts or breakthroughs in addressing problems that occur in the agricultural system.

\section{The Matching Phase in the Raskin Innovation for Food Labor Intensive Patterns}

Matching phase or adjusting or equalizing the situation to the adoption of innovation. This stage provides certainty of the feasibilities or feasibility of the innovation application for the organization. Adjustments are made between organizational problems and the innovations that will be used, then plan and design the application of innovations that are in accordance with the problems at hand ${ }^{24}$.

Adjustments to various criteria in public administration as in (Patton and Sawicki) ${ }^{25}$ can be based on financial posibilities, administrative operability criteria, teachnical feasabilities, and political viability criteria. In the Raskin innovation, the food labor-intensive pattern in Timor Tengah Utara district also has an adjustment to the existing criteria which is applied as a whole so that at the implementation stage it can be maximally as desired.

${ }^{24}$ Erna Setijaningrum. 2016. Inovasi Kebijakan Pelayanan Publik : Best Practice di Indonesia. Airlangga University Press.

25 Patton, CV. \& David S.W. (1986). Basic Methods of Policy Analysis and Planning. USA: PrenticeHal, Inc., Englewood Cliffs,N.J.07632. 
The results of the study are related to the Matcing phase of the Raskin innovation, which is a very important food-intensive pattern. Because the adjustment of innovation can be carried out well if it meets the existing adjustment criteria. The adjustment of the Raskin innovation to the Food Labor Intensive Pattern by the Food Crops and Plantation Agency of Timor Tengah Utara Regency, namely the adjustment of new concepts, financial criteria, technical capabilities, and public support. In the research on Raskin innovation, the food labor-intensive pattern has met the adjustment criteria, but there are not yet some that have not been maximized. Like the financial criteria, namely there is no funding for the implementers at the village level, the technical capability criteria, namely the beneficiary community does not understand the technical implementation of agricultural land management as contained in the Raskin innovation for the food labor-intensive pattern, followed by public support. The community certainly provides support for this innovation, but it is only a formality to get free Raskin rice.

Thus it can be concluded that the matching phase in the Raskin innovation for the food labor-intensive pattern in North Central Timor District has adjusted to several absolute criteria in a policy or program in this case: concept, finance, technical capacity, and public support. The Raskin PKP innovation has adjusted the existing criteria. However, there needs to be optimization in some of the existing criteria so that this innovation is not just a big concept but the explanation of the concept can have an impact on the needs of the community. For example, there is a need for additional finance to support the implementation of the Raskin PKP Innovation in order to provide motivation for implementers in carrying out their duties according to their technical capabilities.

\section{Conclusions}

Based on a discussion of the results of research related to the Pioneering Stages of the Raskin Innovation for Food Labor Intensive Patterns in North Central Timor District, it can be concluded:

1. The Raskin innovation for the Food Labor Intensive Pattern in its formulation has followed the Agenda Setting stage.

2. The Raskin Innovation in the Food Labor Intensive Pattern in North Central Timor Regency is based on the problem of the traditional agricultural system, namely slash and burn which is damaging to the environment. 
3. The beneficiary community for the Food and Labor Intensive Pattern Raskin does not yet understand the technicalities of agricultural land management or the working norms of innovation as contained or regulated in the guidelines.

4. The mindset of the beneficiaries of the PKP Raskin innovation is a formality to get free rice

5. The characteristics of the people of North Central Timor are consumptive.

6. Lack of socialization and assistance by regular implementors of the Raskin PKP innovation.

7. The absence of firmness or binding regulations between the government and the beneficiaries of the PKP Raskin Innovation

8. The Raskin PKP innovation has not yet become a routine work system for the TTU farming community.

9. The Potential of Agricultural Land Area in Timor Tengah Utara Regency, there are still many idle or unprocessed land available.

10. (Human Resources) of the TTU community are inadequate as seen from the level of education.

11. The process of verifying and determining beneficiaries in the village has a political element.

\section{Reference}

Anggaraeny, Cindy. 2013. Inovasi Pelayanan Kesehatan Dalam Meningkatkan Kualitas Pelayanan Di Puskesmas Jagir Kota Surabaya, Jurnal Kebijakan dan Manajemen Publik, Vol 1., No.1 Januari 2013, Unair Surabaya.

Ancok, Djamaludin. 2012. Psikologi Kepemimpinan dan Inovasi. Jakarta : Erlangga.

Anthony, Scott.d. 2013. The Little Black Book Of Innovation Sage Publication, inc.

Badan Pusat Statistik BPS Timor Tengah Utara ,(2019).

Badan Pusat Statistik BPS Provinsi Nusa Tenggara Timur 2020

Bidang Cipta Karya Kabupaten Timor Tengah Utara, 2018

Clark, Jhon \& Ken Guy . 1997. Innovation And Competitiveness. Techopolis.

David O'Sullivan Lawrence Dooley, 2009. Applyng Innovation. Thousand Oaka, CA: Sage 
Dinas Pertanian Tanaman Pangan dan Perkebunan Kabupaten Timor Tengah Utara, 2014.

Erna Setijaningrum. 2016. Inovasi Kebijakan Pelayanan Publik : Best Practice di Indonesia. Airlangga University Press.

Hurley, Robert Hult, Tomas M.Hult, 1998. Innovation, Market Orientation And Organizational Learning: An Integration And Emperical Exampirical" Jurnal of Marketing.

(https://www.menpan.go.id/site/berita-terkini/kementerian-panrb-tetapkantop-40-inovasi-pelayanan-publik-2018).

Kamus Besar Bahasa Indonesia Pusat Bahasa Edisi Keempat. Jakarta: PT. Gramedia Pustaka Utama.

Patton, CV. \& David S.W. (1986). Basic Methods of Policy Analysis and Planning. USA: Prentice-Hal, Inc., Englewood Cliffs,N.J.07632.

Peraturan Menteri Negara Pendayagunaan Aparatur Negara dan Reformasi BirokrasiNo 03 Tahun 2018

Petunjuk Teknis Inovasi Pola Padat Karya Pangan 2014.

Rogers, Everett, M. (2003). Diffusions of Innovations; Fifth Edition. Simon \& Schuster Publisher.

Sinambela, 2013. Reformasi Layanan masyarakat, PT Bumi Aksara Jakarta.

Suwarno, Yogi. 2008. Inovasi di Sektor Publik, Stia-Lan Jakarta.

Sugiyono. (2011). Metode Penelitian Kuantitatif, Kualitatif dan R\&D. Bandung: Penerbit Alfabeta.

Van Den Bar, A.W Den Hawkins. 2005. Penyuluhan Pertanian Agriculture Extension. Kanisius. Yogyakarta. 
